\title{
System nadzorowania jakości procesów spawalniczych zgodny z wymaganiami ISO 3834 w oparciu o standardy ISO 9001 - część 2
}

\author{
Welding process quality supervising system \\ compliant with ISO 3834 standard \\ based on ISO 9001 standards - part 2
}

\section{Streszczenie}

Celem artykułu jest przedstawienie koncepcji zintegrowania wymagań normy spawalniczej ISO 3834 z istniejącą dokumentacją SZJ wg ISO 9001 na przykładzie przedsiębiorstwa branży spawalniczej Prod-Met Sp. z o.o. Założono, że wdrożenie systemu ISO 3834 znacznie poprawi jakość spawanych elementów, usprawni produkcję, obniży koszty i wpłynie na poprawę wizerunku firmy. Wprowadzenie zintegrowanego systemu zarządzania jakością porządkuje zadania przydzielane poszczególnym wydziałom, jasno określa kompetencje pracowników, wprowadza spójność w przedsiębiorstwie i ukierunkowanie na wspólny cel. Zapewniona jest przejrzystość procesów, co znacząco wpływa na efektywność działań firmy. Natychmiastowa reakcja na zaistniałe błędy umożliwia eliminację wad wyrobów jeszcze na etapie produkcji, co znacznie obniża koszty działalności podstawowej przedsiębiorstwa. Wdrożenie zintegrowanego systemu staje się ekonomicznie uzasadnione.

Słowa kluczowe: jakość procesów spawania, ISO 3834

\section{Abstract}

The purpose of the article is to present the idea of integration of welding standard requirements with existing documentation of quality management system according to ISO 9001 using as an example a welding branch company Prod-Met Sp. z o.o. It was assumed that implementation of ISO 3834 system would significantly improve quality of welded workpieces, make production more efficient, reduce costs and influence positively the company image. Implementation of integrated quality management system puts in order tasks assigned to the departments, clearly defines employees' powers, introduces integrity into company and directs company activity to the common goal. The process clearness is assured which significantly rises company activity effectiveness. Immediate reaction to occurring errors enables to eliminate product defects still on production stage, which significantly reduces basic company costs. Implementation of integrated system becomes economically reasonable.

Keywords: welding process quality, ISO 3834 Standard

\section{Koncepcja wdrożenia} systemu nadzorowania jakości procesów spawalniczych zgodnego z wymaganiami ISO 3834 w oparciu o ISO 9001

Bazą do działań związanych z wdrożeniem systemu zarządzania jakością spawania może być istniejący w przedsiębiorstwie system ISO 9001. Pierwszym krokiem jest zintegrowanie dokumentacji ISO 9001 z wymaganiami ISO 3834 oraz opracowanie procedur kontroli zarządzania spawaniem. Konieczne jest, aby firma zatrudniała pracownika posiadającego kwalifikacje inżyniera spawalnika IWE/EWE (ang. International Welding Engineer/European Welding Engineer). Należy również skierować pracowników działu Kontroli Jakości na kurs kwalifikowanego personelu kontroli jakości spawania (RWC). Wykorzystując wiedzę i uprawnienia wyszkolonych pracowników należy wdrożyć Zintegrowany System Zarządzania Jakością procesów spawalniczych w całym zakładzie. Po spełnieniu tych warunków przedsiębiorstwo może zgłosić wniosek do wybranej jednostki certyfikującej o nadanie certyfikatu. Schemat postępowania przy wdrażaniu normy PN-EN ISO 3834 przedstawiono na rysunku 1.

\section{Integracja normy PN-EN ISO 3834 z dokumentacją SZJ ISO 9001}

Projekt wdrożenia ISO 3834 składa się z kilku ważnych etapów, z których pierwszym i najważniejszym elementem jest przygotowanie dokumentacji systemowej. Niewątpliwym ułatwieniem tego zadania może być posiadanie systemu zarządzania jakością zgodnego z ISO 9001 . ISO 3834 zawiera elementy, które można zintegrować z systemem zarządzania jakością wg ISO 9001. Opracowana w ten sposób dokumentacja dotyczy procedur spawalniczych, nadzorowania jakości podczas wszystkich etapów procesu spawania, działań kontrolnych, badań nieniszczących, jak również poprawiania ujawnionych niezgodności. 


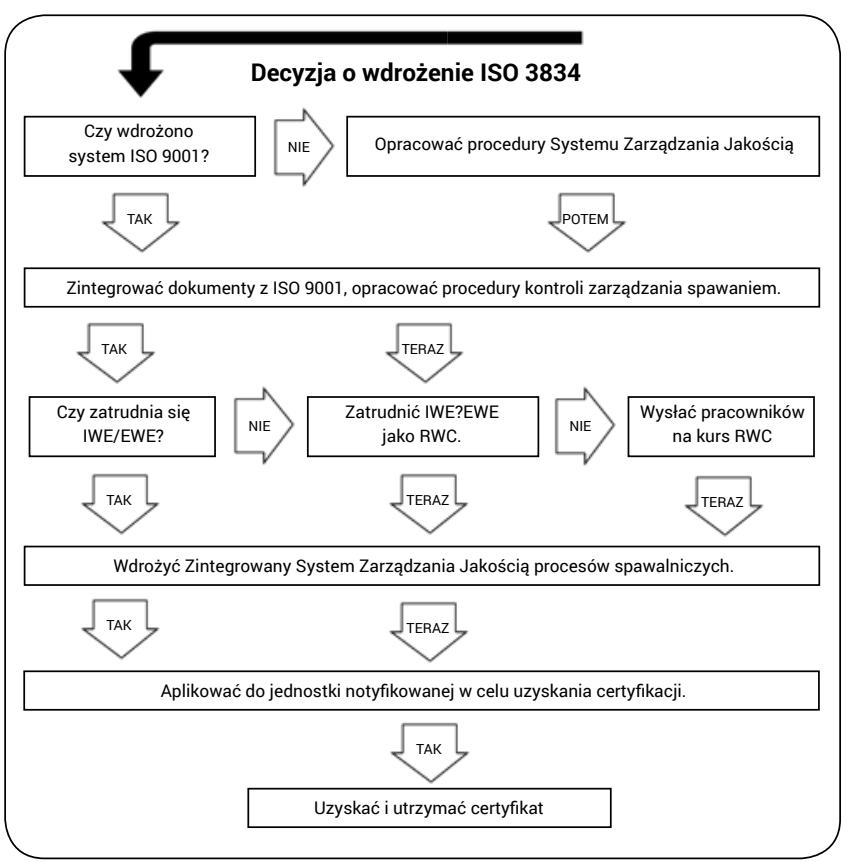

Rys. 1. Schemat wdrożenia normy PN-EN ISO 3834 (źródło: opracowanie własne na podstawie "e-spawalnik")

Fig. 1. Scheme of introduction of PN-EN ISO 3834 standard (source: own case study based on "e-spawalnik")

Mechanizmy działania normy ISO 3834 zintegrowane z wymaganiami normy ISO 9001 w przedsiębiorstwie branży spawalniczej przedstawiono schematycznie na rysunku 2. Głównym celem działań jest zadowolenie klienta. Składając zamówienie klient określa swoje wymagania w specyfikacji, wyrób musi być zgodny z przepisami prawa, odpowiadać normom produkcji.

Poniżej zestawiono elementy ISO 3834, które połączono

z wymaganiami ISO 9001 [6]:

- nadzór nad dokumentami i zapisami,

- odpowiedzialność kierownictwa,

- zarządzanie zasobami,

- kompetencje, świadomość i szkolenie działającego personelu,

- realizacja wyrobu,

- określenie i przegląd wymagań dotyczących wyrobu,

- zakupy,

- walidacja procesów,
- własność klienta,

- audit wewnętrzny,

- monitorowanie i pomiary wyrobu.

Podstawowa dokumentacja przedsiębiorstwa obowiązuje całą działalność handlową, technologiczną, zaopatrzeniową, produkcyjną, kontrolną i odbiorczą stosowaną przy realizacji kontraktów na dostawy. Dokumentacja ta ma zastosowanie we wszystkich komórkach organizacyjnych. Dokumenty opracowywane są na zatwierdzonych formularzach i formatach zgodnie $\mathrm{z}$ obowiązującymi normami i instrukcjami wewnętrznymi firmy. Posiadają one jednoznaczną identyfikację (np. nr formularza, nr pisma), ustaloną wg instrukcji i rejestrów. Oryginały lub autoryzowane kopie dokumentów są archiwizowane w bezpiecznych warunkach przez okres wymagany przepisami prawnymi lub postanowieniami kontraktu. Dokumenty zewnętrzne stosowane w sferze produkcji, w operacjach związanych ze spawaniem materiałów metalowych oraz handlu, podlegają szczególnym wymaganiom i przywołanym instrukcjom.

W skład takich dokumentów wchodzą np.:

- dokumenty zamawiającego,

- dokumenty dostawców,

- normy i przepisy krajowe i zagraniczne.

Odpowiedzialność za stosowanie i doskonalenie Systemu Zarządzania Jakością, nadzorowanie procesów spawalniczych w oparciu o przytoczone normy dotyczy wszystkich komórek organizacyjnych firmy. Prezes Zarządu określa misję i strategię firmy, politykę jakości i cele strategiczne. Powołuje Pełnomocnika ds. Jakości, którego obowiązkiem jest zarządzanie systemem jakości, zapewnienie zgodności z wymaganiami PN-EN ISO 9001 oraz PN-EN 3834. Pełnomocnik ds. Jakości powinien posiadać konieczne uprawnienia do wstrzymania każdego procesu produkcyjnego, w celu usunięcia niezgodności lub potencjalnych niezgodności związanych z jakością.

Zasadniczym i strategicznym celem działalności przedsiębiorstwa, z punktu widzenia SZJ, jest uzyskanie wszechstronnego zadowolenia klientów. Główną drogą do osiągnięcia tego celu jest przyjęta filozofia ciągłego doskonalenia organizacji w realizacji procesów głównych i pomocniczych. System jakości jest poddawany weryfikacji przez planowane przeglądy systemu, audity jakości, kontrole inspekcyjne. W dokumentacji systemu powinny być określone zasady działań weryfikacyjnych, wyznaczony personel do tych działań oraz przedstawione sposoby dokumentowania ich wyników. Działania weryfikacyjne powinny uwzględniać cały cykl

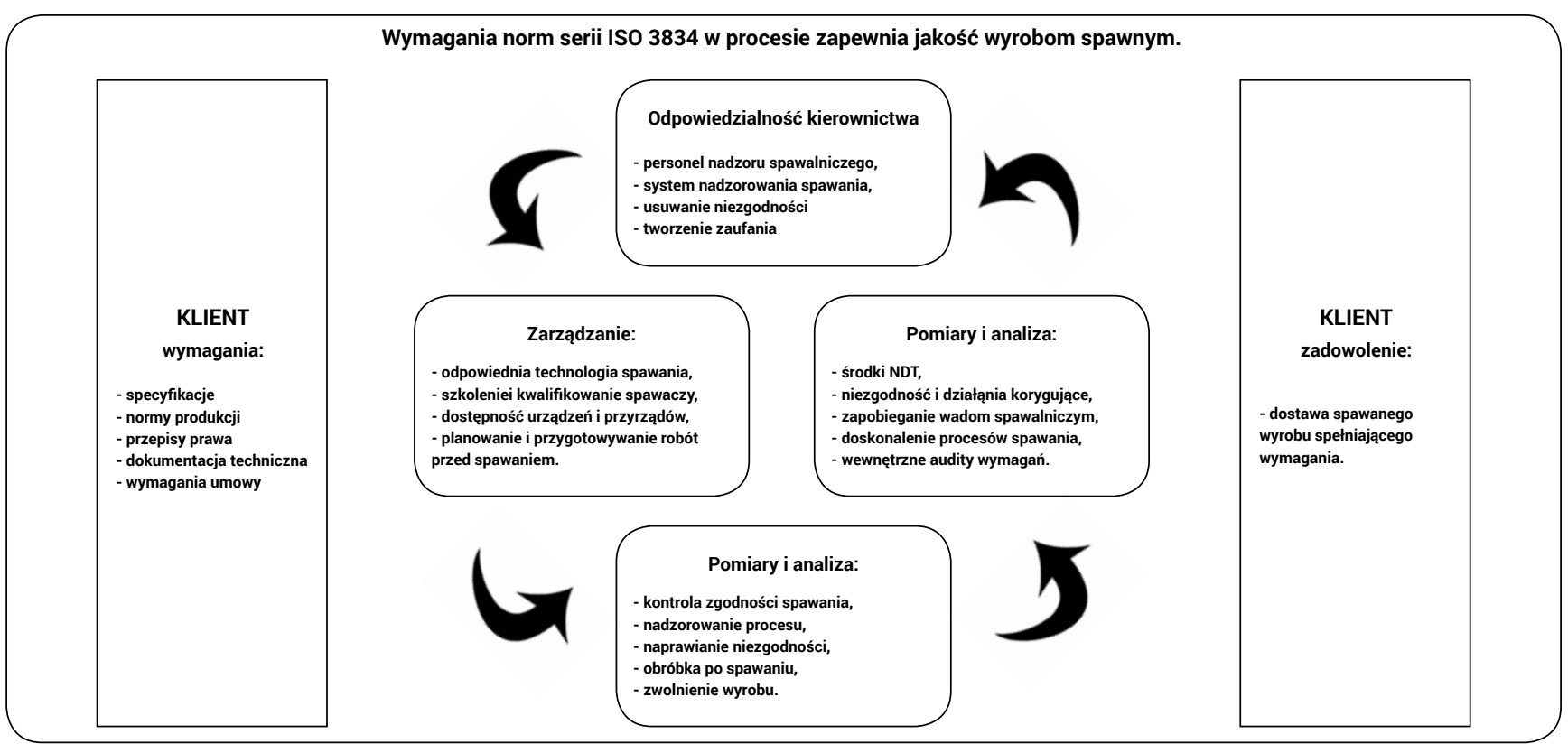

Rys. 2. Spełnianie wymagań normy ISO 3834 (źródło: opracowanie własne na podstawie TÜV Rheinland Polska, www.tuv.pl) Fig. 2. Requirements fulfilling for ISO 3834 standard (source: own case study based on TÜV Rheinland Polska, www.tuv.pl) 
funkcjonowania obejmujący zakupy, produkcję, sprzedaż oraz obszary związane z funkcjonowaniem systemu.

Dokumentacja firmy określa również kwalifikacje pracowników oraz planowanie szkoleń. Dobór pracowników odbywa się zgodnie z wymaganiami dla poszczególnych stanowisk pracy odnośnie wykształcenia, przeszkolenia i doświadczenia. Formułuje się odpowiednie procedury dotyczące szkoleń i uprawnień posiadanych przez pracowników, które mają zastosowanie w wyborze kwalifikowanych kadr na stanowiska kierownicze i wykonawcze oraz zapewnieniu odpowiednich programów szkolenia personelu. W obszarze realizacji prac spawalniczych mogą uczestniczyć tylko osoby wykwalifikowane, które kompetencje i wiedzę uzyskały przez naukę, szkolenie i odpowiednie doświadczenie praktyczne. W celu udokumentowania poziomu kompetencji i wiedzy wymagany jest egzamin kwalifikacyjny przeprowadzony zgodnie z wymaganiami PN-EN 287-1:2011 lub PN EN ISO 9606 „Sprawdzenie kwalifikacji" dla spawaczy oraz PN EN ISO 9712:2012 „Personel badań nieniszczących" dla pracowników KJ.

Przy wykonywaniu prac spawalniczych oprócz dokumentacji technicznej wymagana jest Instrukcja Technologiczna Spawania (WPS) sporządzana przez upoważnionego pracownika nadzoru spawalniczego. Na wszystkich etapach produkcji prowadzona jest kontrola jakości. Pracownik wykonujący operację jest zobowiązany do kontroli jakości wykonania przed przekazaniem elementu do dalszych operacji procesu technologicznego. W ramach samokontroli pracownicy nie muszą prowadzić zapisów. Wszystkie etapy produkcji kontrolowane są przez pracowników Działu Kontroli Jakości. Sprawdzane są wymiary, estetyka wykonania oraz ogólny wygląd wyrobu na każdym etapie realizacji, oględziny i badania nieniszczące spoin zgodnie $z$ dokumentacją techniczną.

Z kontroli półwyrobów i wyrobów gotowych prowadzone są zapisy jakości wykonywane przez kontrolerów. Stwierdzenie odstępstw w trakcie produkcji lub w wyrobie gotowym uruchamia działania korygujące lub zapobiegawcze. Kontroler jakości ocenia, czy stwierdzona niezgodność może być usunięta poprzez działania korygujące. Jeżeli tak, element lub wyrób gotowy przekazywany jest na odpowiednie stanowisko produkcyjne w celu jej usunięcia. Elementy wyrobu lub wyroby gotowe, w których stwierdzono niezgodności przekazane na stanowisko pracy w celu usunięcia niezgodności są oznaczone w sposób gwarantujący, że nie zostaną nieświadomie użyte. Po usunięciu niezgodności element lub wyrób sprawdzany jest ponownie. Po poprawie jest przekazywany do dalszych operacji produkcyjnych a wyrób gotowy do magazynu. Elementy wadliwe są złomowane. Kontroler jakości sporządza raport dzienny ze stwierdzonych niezgodności w podziale na niezgodności usunięte oraz wyroby i półwyroby przekazane do złomowania. Nadzór nad środkami produkcji, urządzeniami i stanowiskami spawalniczymi sprawuje Kierownik Produkcji. W celu spełnienia wymagań normy ISO 3834-5:2007 opracowane są: „Wykaz urządzeń spawalniczych”, „Karta kontroli półautomatów spawalniczych", "Instrukcja magazynowania materiałów pomocniczych do spawania" z integralną z nim "Tabelą monitorowania warunków magazynowania" materiałów podstawowych i pomocniczych do spawania. Szczegóły procesu zawarte są w procedurze "Realizacja produkcji”.

Towary handlowe i wyroby $w$ trakcie ich przyjmowania i składowania zabezpieczane są przed uszkodzeniem bądź zniszczeniem zgodnie z procedurą „Postępowanie z wyrobem". Procedura obowiązuje we wszystkich działach bezpośrednio i pośrednio związanych ze składowaniem oraz transportowaniem towarów handlowych i wyrobów gotowych. Kierownik Magazynu odpowiada za prawidłowe składowanie towarów handlowych oraz wyrobów produkcji własnej, za proces przyjmowania oraz wydawania towarów zgodnie z dokumentacją handlową. Wszystkie towary handlowe oraz wyroby z produkcji własnej przyjmowane są do magazynów firmy i składowane tak, aby nie traciły swoich właściwości technicznych ani nie były narażone na zniszczenie. Przechowuje się je w magazynach zamkniętych, suchych, na wydzielonych regałach, paletach lub w oznakowanych opakowaniach fabrycznych.

Zgodnie z procedurą "Przegląd umowy" sprawdza się wszystkie umowy przed podpisaniem a oferty przed złożeniem w celu stwierdzenia czy wymagania klienta zostały określone i uzgodnione. Ewentualne różnice między umową a ofertą powinny być wyjaśniane. Wyznaczeni pracownicy dokonują przeglądu wymagań i danych technicznych dostarczonych przez odbiorcę. Ustalają, czy wszystkie informacje konieczne do wykonania operacji wytwarzania są kompletne i dostępne przed rozpoczęciem pracy. Sprawdza się, czy środki do produkcji są wystarczające do zachowania terminów dostaw wyrobów odpowiedniej jakości. Z opisanych powyżej czynności prowadzone są zapisy.

Działania związane z kontrolą i badaniem dostaw surowców, materiałów, towarów handlowych objęte są procedurą "Kontrola i badania w produkcji”. Procedura zapewnia, że do procesu produkcyjnego, a następnie do odbiorcy, będą przekazywane wyroby spełniające wymagania. Procedura obejmuje produkcję, sprzedaż wyrobów własnych i towarów handlowych na każdym etapie realizacji tych procesów z uwzględnieniem spawania materiałów metalowych. Odpowiedzialnym za utrzymywanie procedury w zakresie kontroli dostaw zakupionych usług, materiałów i surowców jest pracownik przyjmujący dany materiał, usługę bądź towar handlowy. Funkcję kontrolną nad dostawami materiałów podstawowych i dodatkowych do spawania sprawuje Kierownik Produkcji oraz Główny Spawalnik. Odpowiedzialnymi za utrzymywanie procedury $w$ zakresie kontroli w toku realizacji produkcji są pracownicy realizujący wyrób w ramach samokontroli wykonywanych robót, pracownicy KJ w zakresie badań nieniszczących spoin, Kierownik Produkcji i Kierownik Magazynu, każdy w swoim zakresie oraz Pełnomocnik ds. Jakości sprawujący nadzór nad procesami kontroli.

Dostawa materiałów do produkcji realizowana jest w ramach zintegrowanej dokumentacji systemowej w procedurze "Zakupy". Zakres procedury obejmuje zakupy wszystkich materiałów i surowców oraz usług, jak również materiałów podstawowych i dodatkowych związanych ze spawaniem wyrobów metalowych.

Przed wdrożeniem wyrobu do produkcji, należy porównać jego zgodność wymiarową oraz cechy jakościowe z zamówieniem klienta. Na rysunku 3 przedstawiono przykładowe wytyczne Zakładowej Kontroli Jakości procesów spawalniczych.

\section{ProdNet}

Sp. zo.o.

PM-KJ-S001:2012

Wytyczne Zakładowej Kontroli Jakości procesów spawalniczych

1. Przed wdrożeniem do produkcji przeprowadzić szczegółową walidacjẹ wyrobu w oparciu

o dane zebrane przez handlowców i konstruktorów.

2. Porównać zgodność wyrobu z zamówieniem klienta

3. Sprawdzić min $5 \%$ detali pod względem:

- estetyki wykonania spoin spawalniczych ze szczególnym zwróceniem uwagi na odpryski i wtopione resztki drutu spawalniczego.

- w razie uzasadnionych podejrzeń co do trwałości polączeń wykonać próbẹ zniszczeniową.

4. Skontrolować min. $5 \%$ wyrobów pod kątem zachowania wymiarów spawanego detalu lub jego części z zachowaniem tolerancji warsztatowej, o ile nie jest podana inna tolerancja.

Rys. 3. Wytyczne zakładowej kontroli jakości (źródło: materiały wewnętrzne firmy Prod-Met Sp. z o.o.)

Fig. 3. Guidelines for facility quality control (source: internal documents of Prod-Met Sp. z o.o.) 
Kontrola wyrobów dokonywana jest na każdym etapie realizacji przez pracowników KJ zgodnie z procedurami „Kontrola i badania w produkcji” oraz „Sprzęt kontrolno-pomiarowy", która zapewnia, że sprzęt używany do pomiarów jest nadzorowany, sprawdzany i konserwowany w sposób zapewniający sprawność, a zdolność pomiarowa - znana i zgodna z wymaganiami. Systemy pomiarowe powinny być stabilne i zdolne do oceny nie tylko jakości wyrobów spawanych, ale również parametrów procesu spawania [4,5].

Tablica I. Harmonogram wdrożenia systemu (opracowanie własne) Table I. System implementation timechart (source: own case study)

\begin{tabular}{|c|c|c|c|c|c|c|c|}
\hline \multirow{2}{*}{ Lp. } & \multirow{2}{*}{ Opis zadania } & \multicolumn{6}{|c|}{ Termin realizacji } \\
\hline & & I & II & III & IV & V & VI \\
\hline 1 & $\begin{array}{l}\text { Audit wstępny (diagnoza } \\
\text { stanu obecnego) }\end{array}$ & & & & & & \\
\hline 2 & $\begin{array}{c}\text { Opracowanie dokumentacji } \\
\text { systemowej }\end{array}$ & & & & & & \\
\hline 3 & Szkolenia & & & & & & \\
\hline 4 & Wdrażanie procedur & & & & & & \\
\hline 5 & $\begin{array}{l}\text { Audity wewnętrzne } \\
\text { (działania korygujące) }\end{array}$ & & & & & & \\
\hline 6 & Audit certyfikujący & & & & & & \\
\hline
\end{tabular}

\section{Harmonogram wdrożenia systemu nadzorowania jakości procesów spawalniczych zgodnego $z$ wymaganiami ISO 3834 w oparciu o ISO 9001}

Harmonogram został opracowany na półroczny okres wdrażania (tabl. I). W pierwszym miesiącu od podjęcia decyzji o przystąpieniu do certyfikacji firma konsultingowa wykonuje diagnozę stanu obecnego czyli przeprowadza audit wstępny, w celu uzyskania obrazu firmy, znalezienia mocnych i słabych stron, które należy korygować. W tym samym czasie zaczyna się opracowywanie dokumentacji systemowej. Polega to na integracji procedur z wdrożonego już wcześniej systemu ISO 9001 z procedurami spawalniczymi ISO 3834. Na kompletne zintegrowanie procedur i przygotowanie zakładu do ich wdrożenia przewiduje się trzy miesiące. Prawie jednocześnie z opracowywaniem dokumentacji należy rozpocząć szkolenia według ułożonego planu. Szkolenia obejmują wszystkich zainteresowanych pracowników, począwszy od kierownictwa, pełnomocnika, poprzez kontrolerów jakości na spawaczach skończywszy. Kursy i szkolenia trwają cztery miesiące, aż do auditu certyfikującego. Równolegle ze szkoleniami następuje wdrażanie procedur, rozłożone na trzy miesiące. Pod koniec tego etapu należy rozpocząć audity wewnętrzne. Auditorzy wewnętrzni sprawdzają stopień przygotowania zakładu, poziom wdrożenia procedur, ustalają działania korygujące [6].

Po przeprowadzeniu auditów wewnętrznych we wszystkich komórkach organizacyjnych można zgłosić gotowość do auditu certyfikującego.

\section{Wnioski}

Firma Prod-Met działa na rynku od 30 lat jako producent wyrobów z metalu. Najważniejszym procesem produkcyjnym zachodzącym w zakładzie jest spawanie. Od jakości spawania zależy jakość kompletnego wyrobu. Musi on spełniać wysokie wymagania klientów co do wytrzymałości, ale i estetyki wykonania. Zakład przez cały czas dąży do doskonalenia jakości we wszystkich dziedzinach funkcjonowania. Dlatego został wdrożony kompleksowy system zarządzania oparty na normach ISO 9001 i podjęta decyzja o wdrożeniu systemu ISO 3834 ściśle związanego z procesami spawania.

Celem artykułu było zaproponowanie spójnej koncepcji wdrożenia systemu nadzorowania jakości procesów spawalniczych zgodnego $z$ wymaganiami ISO 3834. W oparciu o już funkcjonujące procedury ISO 9001 opracowano wytyczne do ujednolicenia procedur z normą spawalniczą. Opracowano i zaprezentowano przykładowe procedury SZJ ISO 9001:2008 zintegrowane z dokumentacją PN-EN ISO 3834:2007. Stworzono instrukcje spawania WPS, które w bardzo szczegółowy sposób pokazują parametry prawidłowo przebiegającego procesu łączenia materiałów.

Wykazano, że nawet w niedużym zakładzie produkcyjnym bardzo istotne jest wdrożenie zintegrowanych systemów zarządzania i szkolenie kadry. Planowane szkolenia obejmują kluczowy personel, nie tylko kadry zarządzającej, ale przede wszystkim pracowników bezpośrednio zaangażowanych w proces produkcji i kontroli. Równie ważną kwestią jest harmonogram wdrożenia, który musi być realny do wykonania oraz budżet.

Wyniki badań własnych spoin pokazały, że w przedsiębiorstwie należy zwrócić szczególną uwagę na procesy spawania. Każda firma powinna być zorientowana na osiągnięcie sukcesu poprzez zadowolenie swoich klientów. Aby zapewnić, że produkty są trwałe i niezawodne niezbędne jest wprowadzenie szczegółowego nadzoru nad spawaniem. Wprowadzenie zintegrowanego systemu zarządzania jakością porządkuje zadania przydzielane poszczególnym wydziałom, jasno określa kompetencje pracowników, wprowadza spójność w przedsiębiorstwie i ukierunkowanie na wspólny cel. Firma może działać efektywniej na bazie jasnych i przejrzystych procesów zdefiniowanych w instrukcjach i procedurach. Natychmiastowa reakcja na zaistniałe błędy umożliwia eliminację wad wyrobów jeszcze na etapie produkcji co znacznie obniża koszty działalności podstawowej przedsiębiorstwa. Wdrożenie zintegrowanego systemu staje się ekonomicznie uzasadnione.

Wdrożenie systemu ISO 3834 zintegrowanego z wymaganiami normy ISO 9001 znacznie poprawia jakość spawanych elementów, usprawnia produkcję, obniża koszty, wpływa na poprawę wizerunku firmy, dzięki czemu zwiększa się nie tylko wolumen zamówień, ale również asortyment oferowanych wyrobów.

\section{Literatura}

[1] Chmielewski T.: Projektowanie procesów technologicznych. Spawalnictwo. OWPW. Warszawa, 2013

[2] Bagiński J.: Zarządzanie jakością. Oficyna Wydawnicza Politechniki Warszawskiej. Warszawa, 2004

[3] Werpachowski W.: Podstawy zarządzania w przedsiębiorstwie. Oficyna Wydawnicza Politechniki Warszawskiej. Warszawa, 2011.

[4] Sałaciński T.: SPC - Statystyczne sterowanie procesami produkcji. Oficyna Wydawnicza Politechniki Warszawskiej. Warszawa, 2009.

[5] Sałaciński T.: SPC - Statistical process control. Oficyna Wydawnicza Politechniki Warszawskiej. Warszawa, 2015.

[6] Sosnowski W.: Koncepcja wdrożenia systemu nadzorowania jakości procesów spawalniczych zgodnego z wymaganiami ISO $3834 \mathrm{w}$ oparciu o standardy ISO 9001 w przedsiębiorstwie wytwarzającym konstrukcje metalowe. Praca magisterska napisana pod kierunkiem T. Sałacińskiego. Politechnika Warszawska, 2014.
[7] Norma ISO 9001:2008. Systemy zarządzania jakością - Wymagania.

[8] PN-EN ISO 3834-1:2007. Wymagania jakości dotyczące spawania materiałów metalowych. Część 1: Kryteria wyboru odpowiedniego poziomu wymagań.

[9] PN-EN ISO 3834-2:2007. Wymagania jakości dotyczące spawania materiałów metalowych. Część 2: Pełne wymagania jakościowe.

[10] PN-EN ISO 3834-4:2007. Wymagania jakości dotyczące spawania materiałów metalowych. Część 4: Podstawowe wymagania jakościowe.

[11] PN-EN ISO 3834-5:2007. Wymagania jakości dotyczące spawania materiałów metalowych. Część 5: Dokumenty konieczne do potwierdzenia zgodności z wymaganiami jakości ISO 3834-2.

[12] PN-EN ISO 9000:2006. Systemy Zarządzania jakością. Podstawy i terminologia

[13] PN-EN ISO 14175:2009. Gazy i mieszaniny gazów do spawania i procesów pokrewnych.

[14] http://ojakosci.pl/liczba-certyfikatow-iso-9001-w-polsce/

[15] http://spawalnicy.com.pl/jakosc_iso3834.html

[16] http://www.e-spawalnik.pl/?systemy-jakosci-w-spawalnictwie,159

[17] http://www.tuv.pl 